Supporting Information

for

\title{
Carbon-supported $\mathrm{Mg}$-Al oxide hybrid catalysts for
}

\section{aqueous ethanol conversion into 1-butanol in a flow}

\section{reactor}

Olga V. Larina, ${ }^{1 *}$ Pavlo I. Kyriienko, ${ }^{1}$ Nataliya D. Shcherban, ${ }^{1}$ Pavlo S. Yaremov, ${ }^{1}$ Dmytro Yu. Balakin, ${ }^{2}$ Ivan Khalakhan, ${ }^{3}$ Katerina Veltruská, ${ }^{3}$ Sergiy O. Soloviev, ${ }^{1}$ Svitlana M. Orlyk ${ }^{1}$

${ }^{1}$ L.V. Pisarzhevskii Institute of Physical Chemistry, The National Academy of Sciences of Ukraine, 31 Prosp. Nauky, 03028 Kyiv, Ukraine.

${ }^{2}$ Institute of Physics, The National Academy of Sciences of Ukraine, 46 Prosp. Nauky, 03028 Kyiv, Ukraine.

${ }^{3}$ Department of Surface and Plasma Science, Faculty of Mathematics and Physics, Charles University, V Holešovičkách 2, 18000 Prague, Czech Republic.

\section{Corresponding Author}

*olga.larina@ukr.net (O.V. Larina). 
Table of Contents

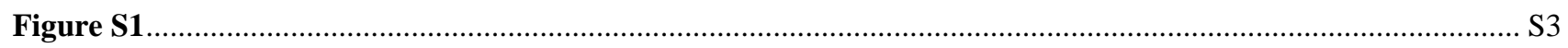

Figure S2

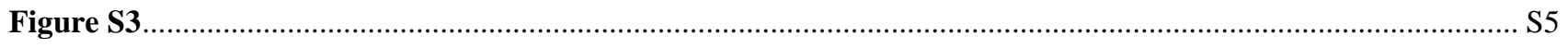

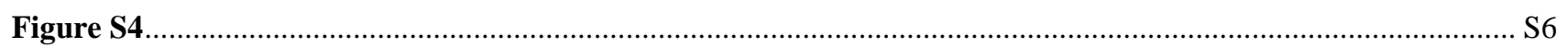

Figure S5

Figure S6 .

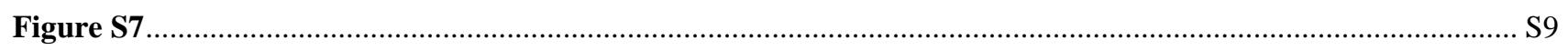

Figure S8

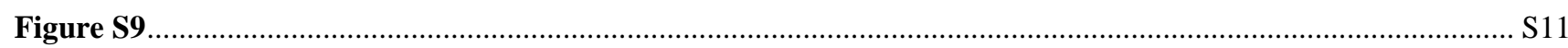

Figure S10

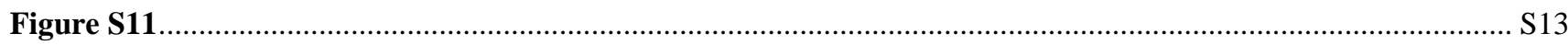

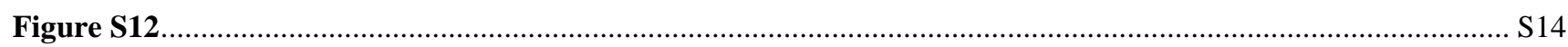

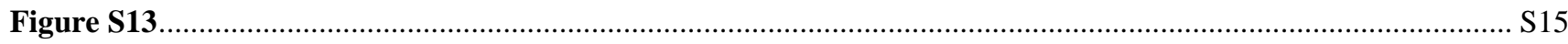

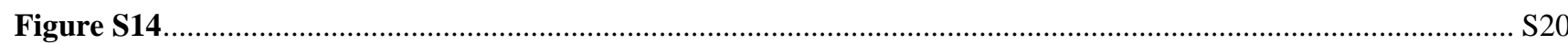

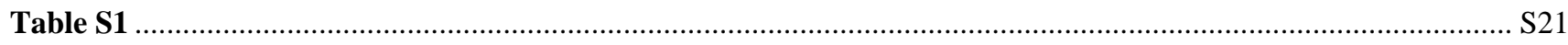

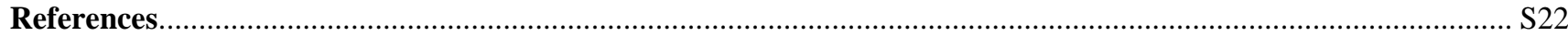



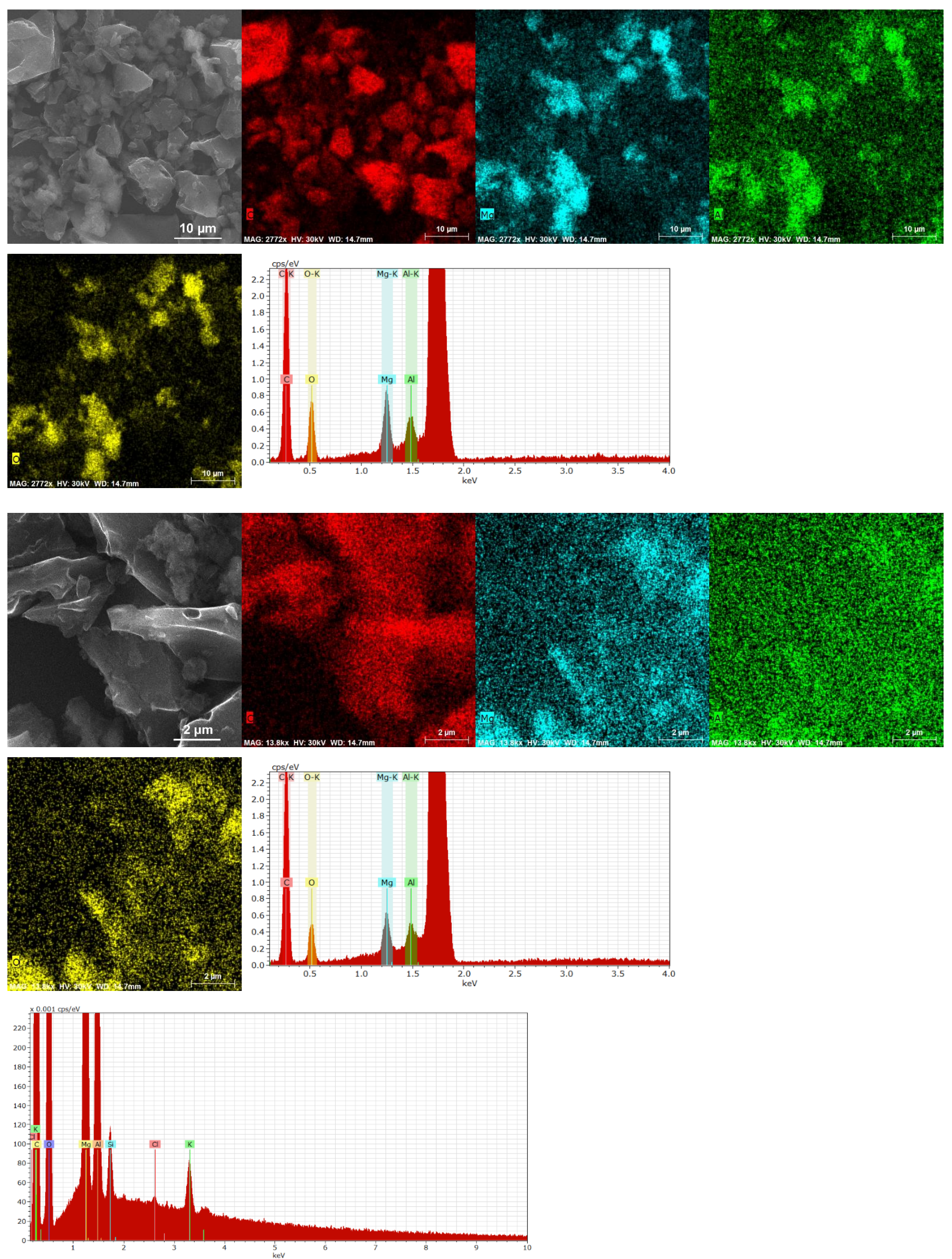

Figure S1. EDX maps in false colors at two magnifications showing the distribution of the elements $(\mathrm{Mg}, \mathrm{Al}$ and $\mathrm{O})$ of the active phase on the $\mathrm{AC}$ support for the calcined $40 \mathrm{Mg}-\mathrm{Al} / \mathrm{AC}$ sample and the corresponding EDX spectra. 

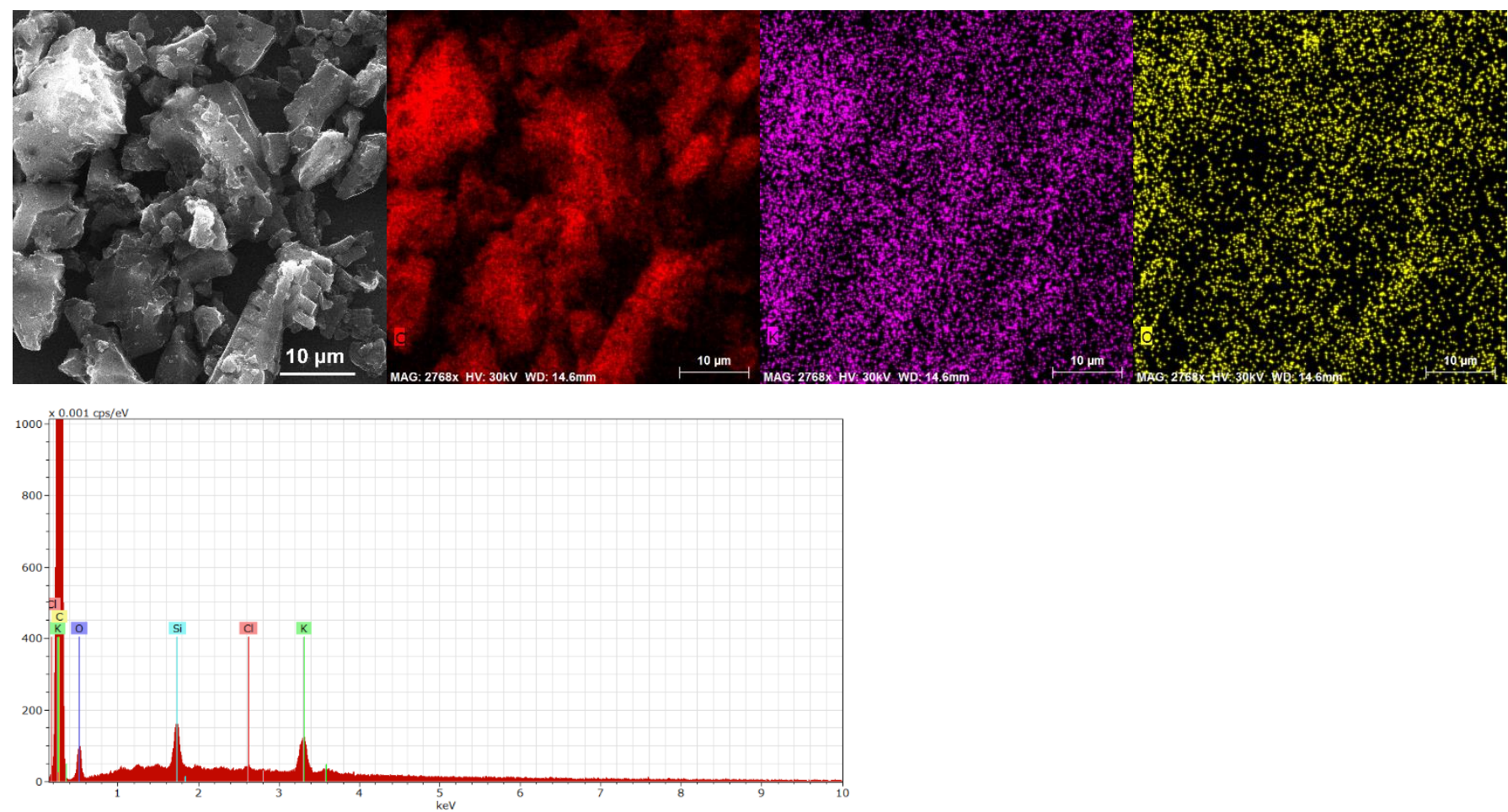

Figure S2. EDX maps in false colors showing the distribution of the elements (C, K and O) and the EDX spectrum of the AC support. 


\section{$\mathrm{Mg}-\mathrm{Al}$}

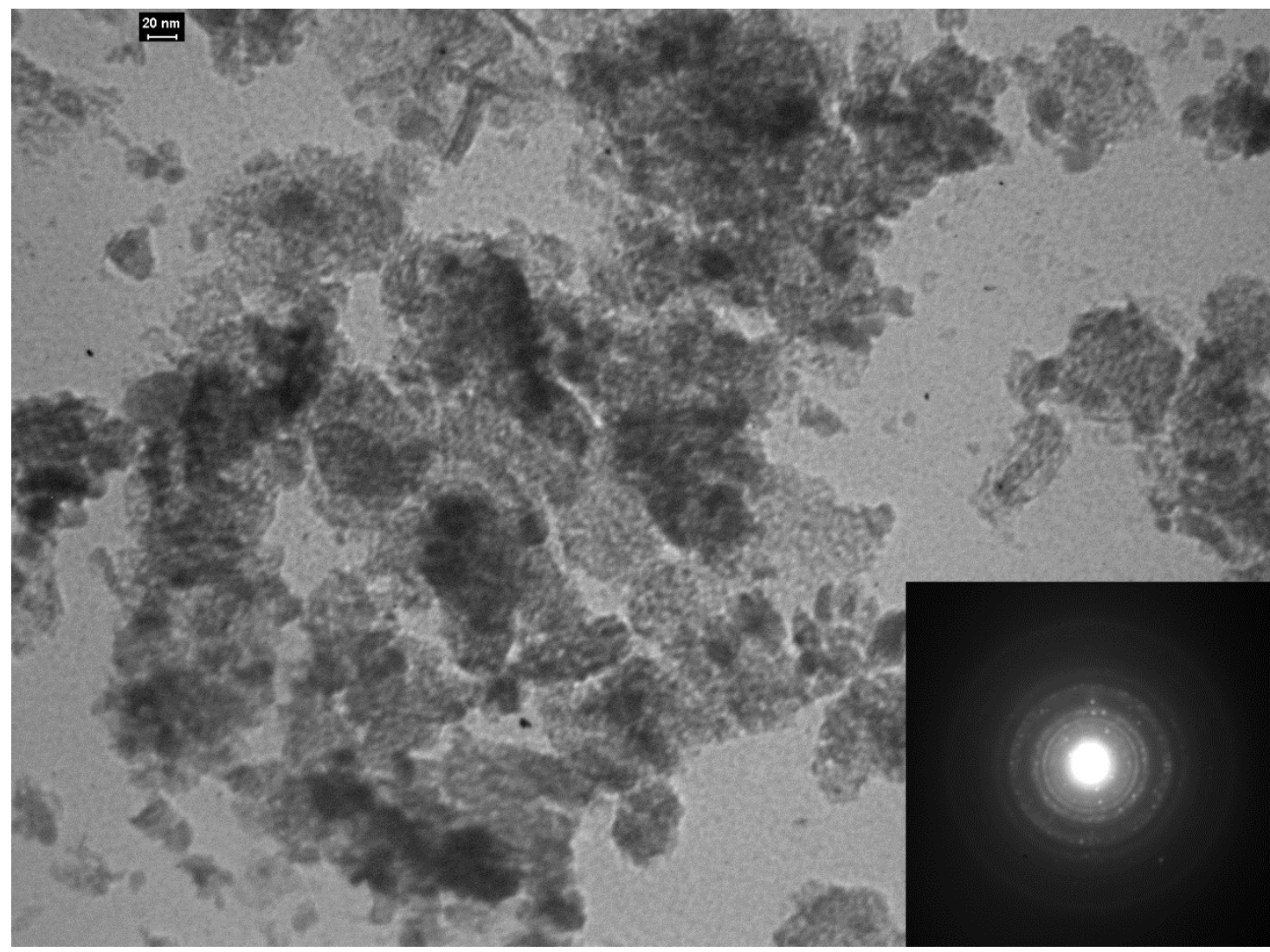

$40 \mathrm{Mg}-\mathrm{Al} / \mathrm{AC}$

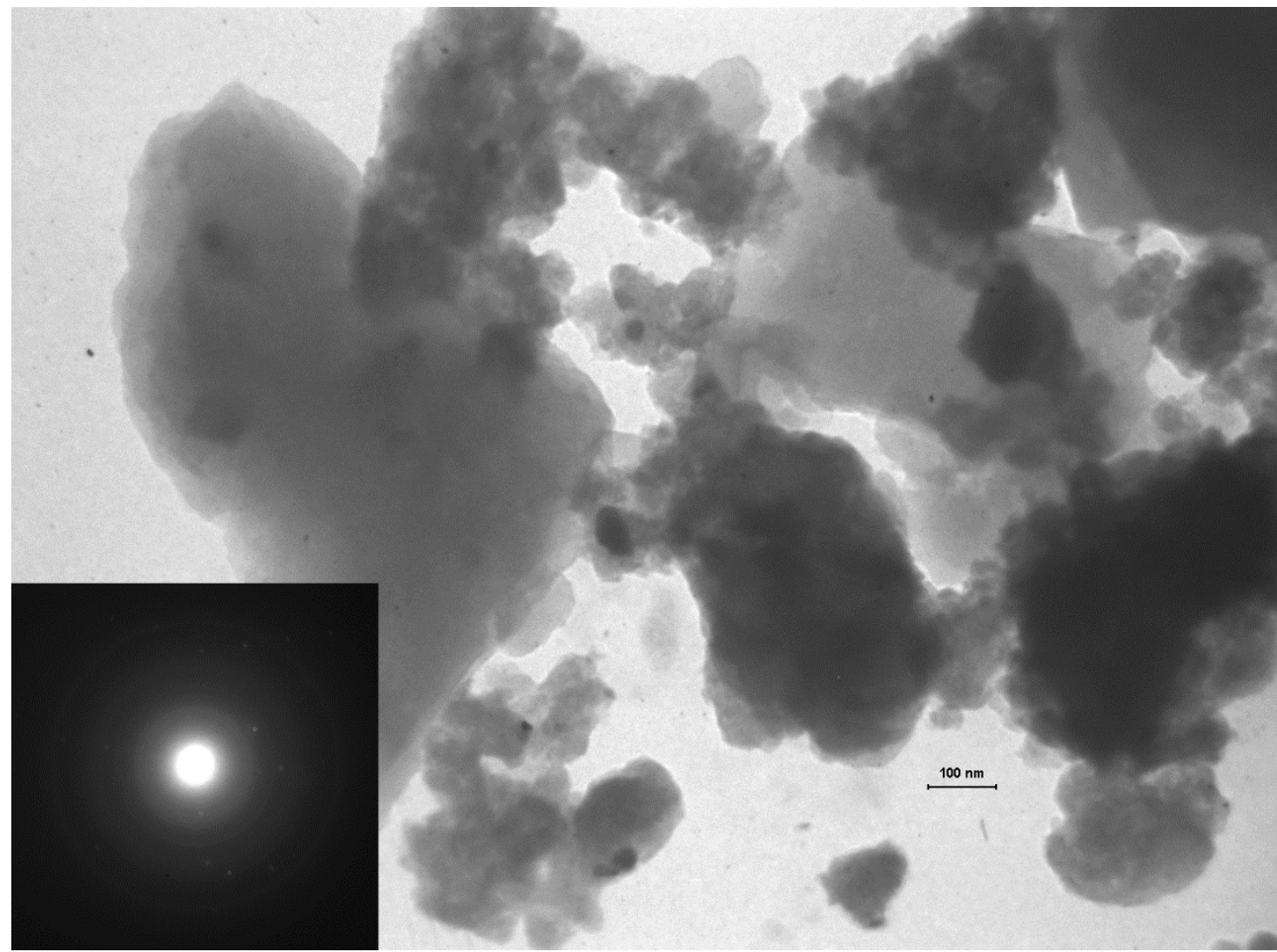

Figure S3. Transmission electron microscopy images of the calcined samples of $40 \mathrm{Mg}-\mathrm{Al} / \mathrm{AC}$ and $\mathrm{Mg}-\mathrm{Al}$. 


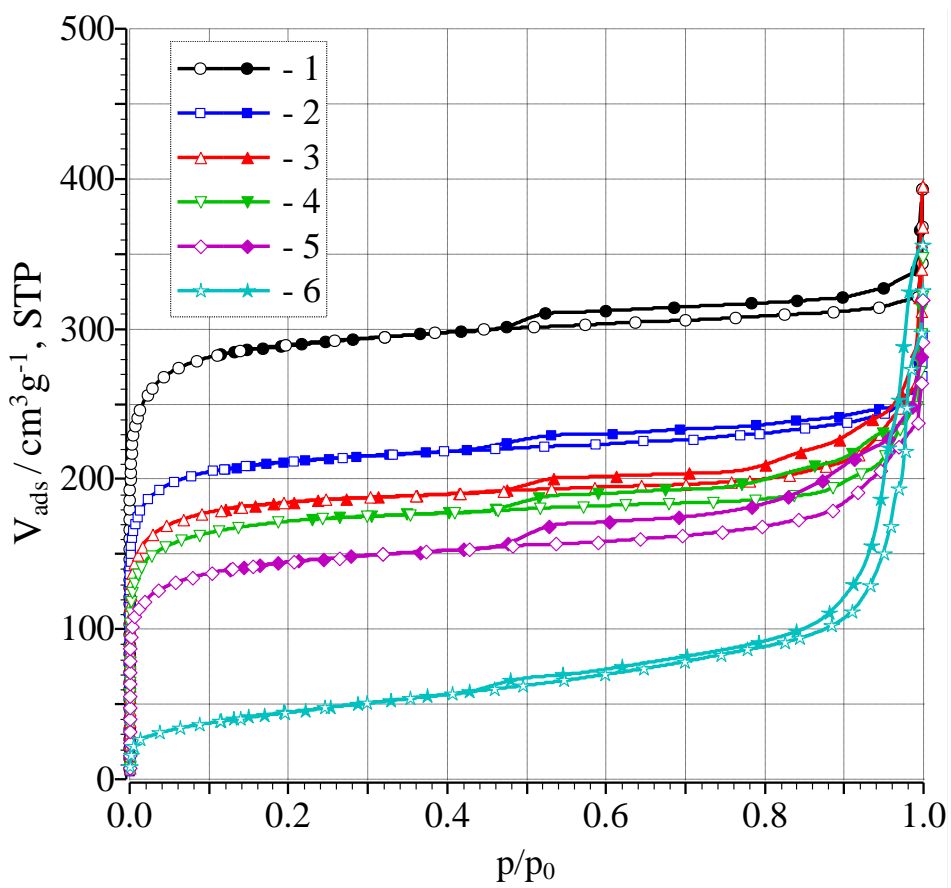

Figure S4. Nitrogen ad(de)sorption isotherms at $77 \mathrm{~K}$ for the samples: $1-\mathrm{AC}, 2-20 \mathrm{Mg}-\mathrm{Al} / \mathrm{AC}, 3-30 \mathrm{Mg}-\mathrm{Al} / \mathrm{AC}, 4-40 \mathrm{Mg}-$ $\mathrm{Al} / \mathrm{AC}, 5-50 \mathrm{Mg}-\mathrm{Al} / \mathrm{AC}, 6$ - Mg-Al. 


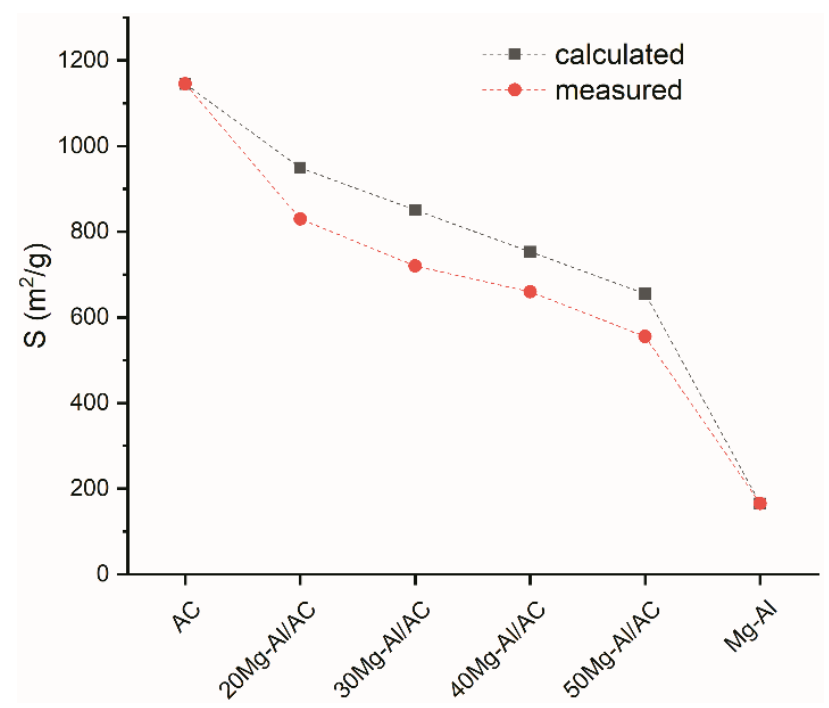

Figure S5. Experimentally determined and calculated specific surface area of $\mathrm{Mg}-\mathrm{Al} / \mathrm{AC}$ system depending on the content of $\mathrm{Mg}$ - $\mathrm{Al}$ active phase in its composition. The experimentally determined values were measured by the BET method. The calculated values of the specific surface area were calculated by the following equation:

$$
S_{\text {calculated }}=\mathcal{W}_{M g-A l} \cdot S_{B E T_{M g-A l}}+\mathcal{W}_{A C} \cdot S_{B E T_{A C}}
$$

here $\mathcal{W}_{M g-A l}, \mathcal{W}_{A C}$ is the mass fractions of $\mathrm{Mg}$ - $\mathrm{Al}$ active phase and $\mathrm{AC}$ support in the composition of $\mathrm{Mg}$ - $\mathrm{Al} / \mathrm{AC}$ system; $S_{B E T_{M g-A l}}, S_{B E T_{A C}}$ is the measured specific surface area of $\mathrm{Mg}$ - $\mathrm{Al}$ active phase and $\mathrm{AC}$ support. 


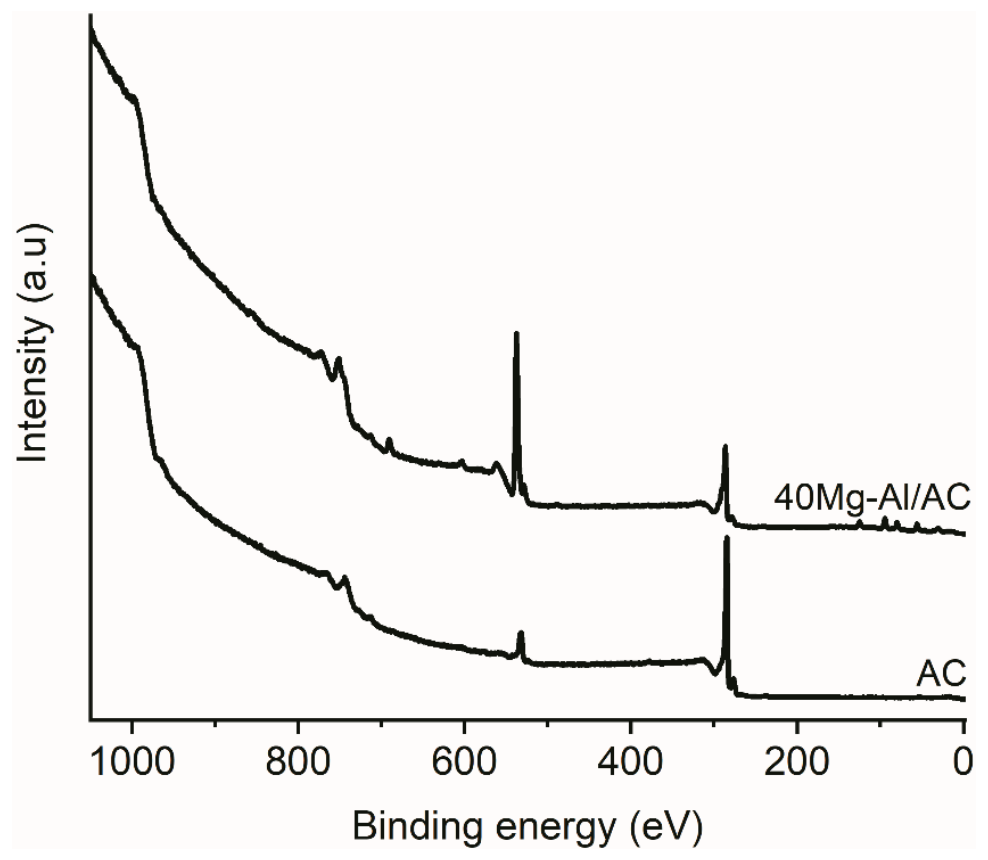

Figure S6. Wide XP spectra for $40 \mathrm{Mg}-\mathrm{Al} / \mathrm{AC}$ sample and the AC support. 


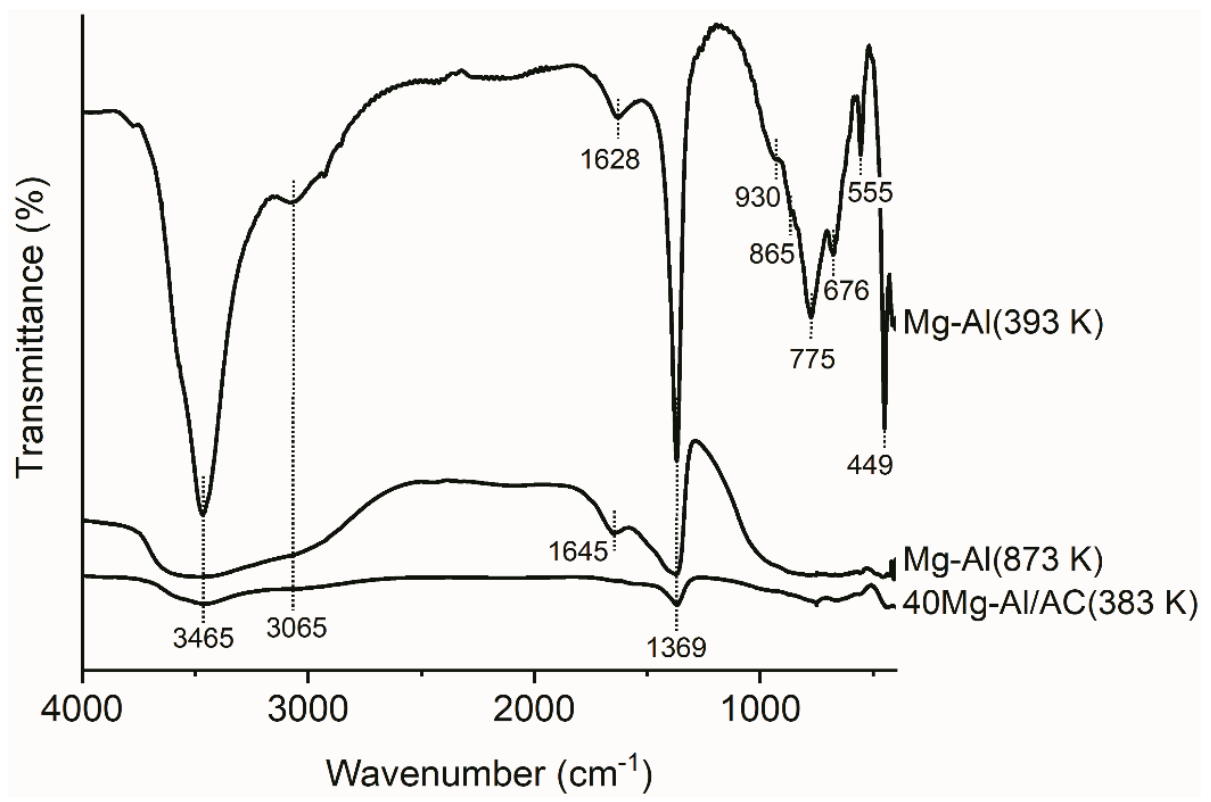

Figure S7. FTIR spectra of 40Mg-Al/AC sample and the $\mathrm{Mg}-\mathrm{Al}$ active phase after drying (383-393 $\mathrm{K})$ and calcination (873 $\mathrm{K}$ ).

FTIR spectra of the Mg-Al active phase (Figure S5) present broad vibration centered respectively at $3465 \mathrm{~cm}^{-1}$, that is vibration due to $\mathrm{OH}$ stretching of sorbed water in the interlayer space ${ }^{1,2}$. For the non-calcined sample of $\mathrm{Mg}$ - $\mathrm{Al}$ (drying temperature of $393 \mathrm{~K}$ ) the peak intensity is high and decreases with increasing the calcination temperature (873 K). This is due to water loss during calcination. The shoulder at $3065 \mathrm{~cm}^{-1}$ in the spectrum of the non-calcined $\mathrm{Mg}$-Al sample can be caused by the bond between $\mathrm{CO}_{3}{ }^{2-}$ and water in the space between the hydrotalcite layers. Bending vibrations of OH groups are observed in the region of $1645-1628 \mathrm{~cm}^{-1}$ for both calcined and non-calcined $\mathrm{Mg}$-Al samples. The intensity decrease with increasing the calcination temperature of the $\mathrm{Mg}-\mathrm{Al}$ active phase is also observed for a strong vibration at $1369 \mathrm{~cm}^{-1}\left(v_{3} \mathrm{CO}_{3}{ }^{2-}\right.$ stretching mode), which corresponds to the interaction between the $\mathrm{CO}_{3}{ }^{2-} \mathrm{COO}$ and the $\mathrm{OH}$ group belonging to the octahedral structure of hydrotalcite ${ }^{3} . v_{4} \mathrm{CO}_{3}{ }^{2-}$ stretching mode is recorded at $676 \mathrm{~cm}^{-1}$ and $\mathrm{v}_{2} \mathrm{CO}_{3}{ }^{2-}$ stretching mode is recorded at $865 \mathrm{~cm}^{-1}$ only for the non-calcined Mg-Al sample. Wherein, the bands at lower values than $1000 \mathrm{~cm}^{-1}$ are also associated with the metal-oxygen vibrations. Al-OH translation mode is observed at $930 \mathrm{~cm}^{-1}$. The bands at 775 and $555 \mathrm{~cm}^{-1}$ correspond to $v \mathrm{Al}-\mathrm{O}{ }^{4}$. Intensive vibration at $449 \mathrm{~cm}^{-1}$ can be ascribed to the stretching vibration of $\mathrm{Mg}-\mathrm{O}-\mathrm{Al}{ }^{5}$. FTIR spectra of $40 \mathrm{Mg}-\mathrm{Al} / \mathrm{AC}$ sample present broad vibration at $3465 \mathrm{~cm}^{-1}\left(\mathrm{OH}\right.$ stretching of sorbed water) and narrow vibration at $1369 \mathrm{~cm}^{-1}\left(\mathrm{v}_{3} \mathrm{CO}_{3}{ }^{2-}\right.$ stretching mode). 
A
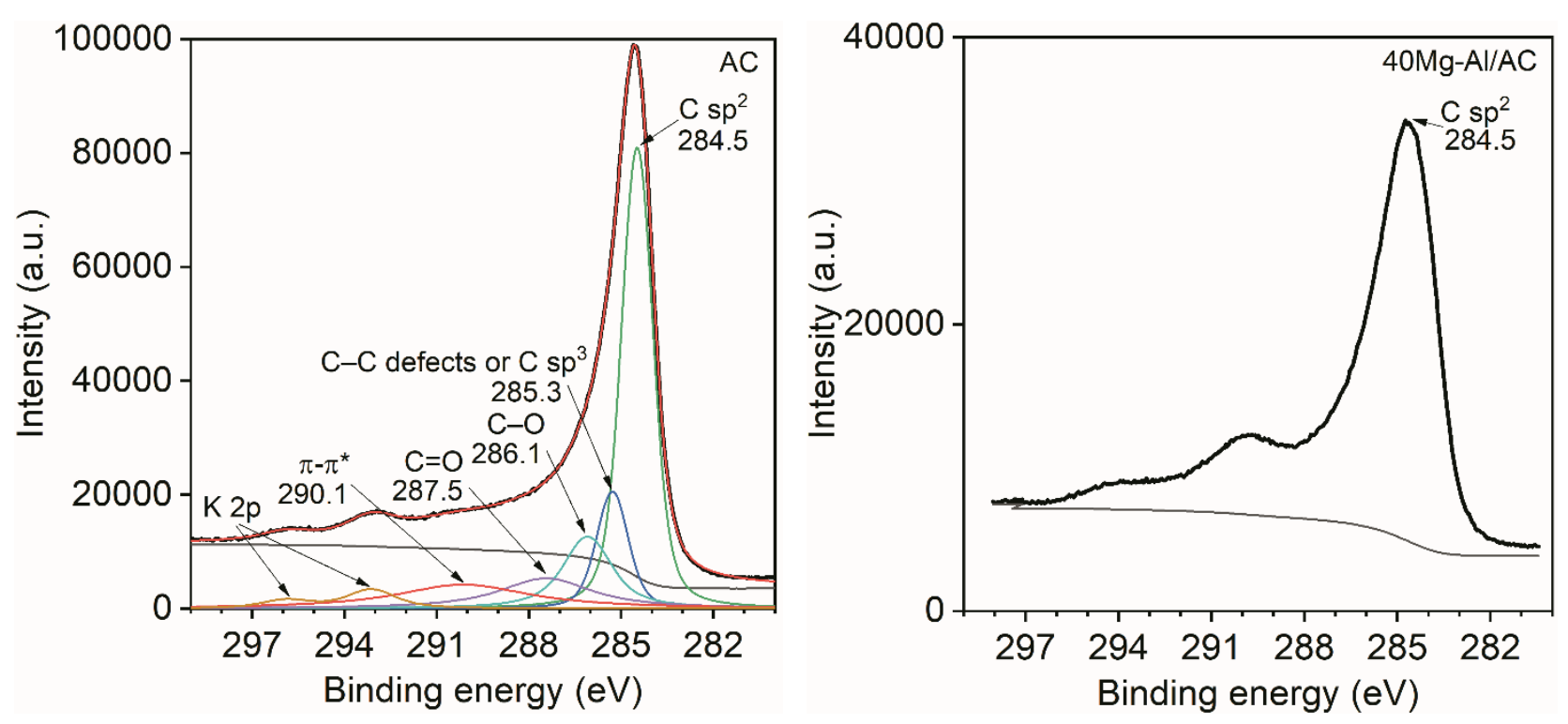

B
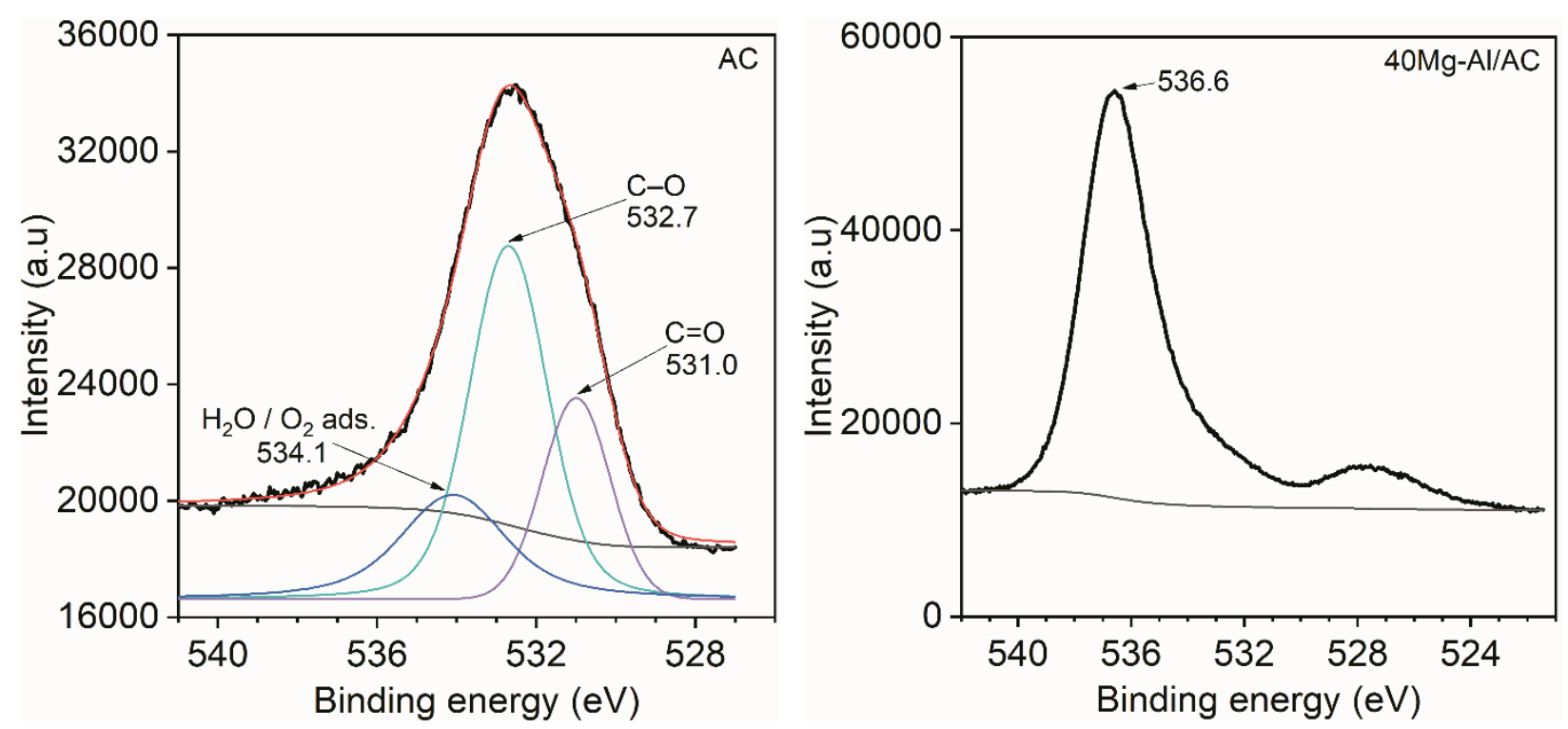

Figure S8. High resolution C 1s (A) and O 1s (B) XP spectra for 40Mg-Al/AC sample and the AC support after catalysis, and corresponding fitting curves. 

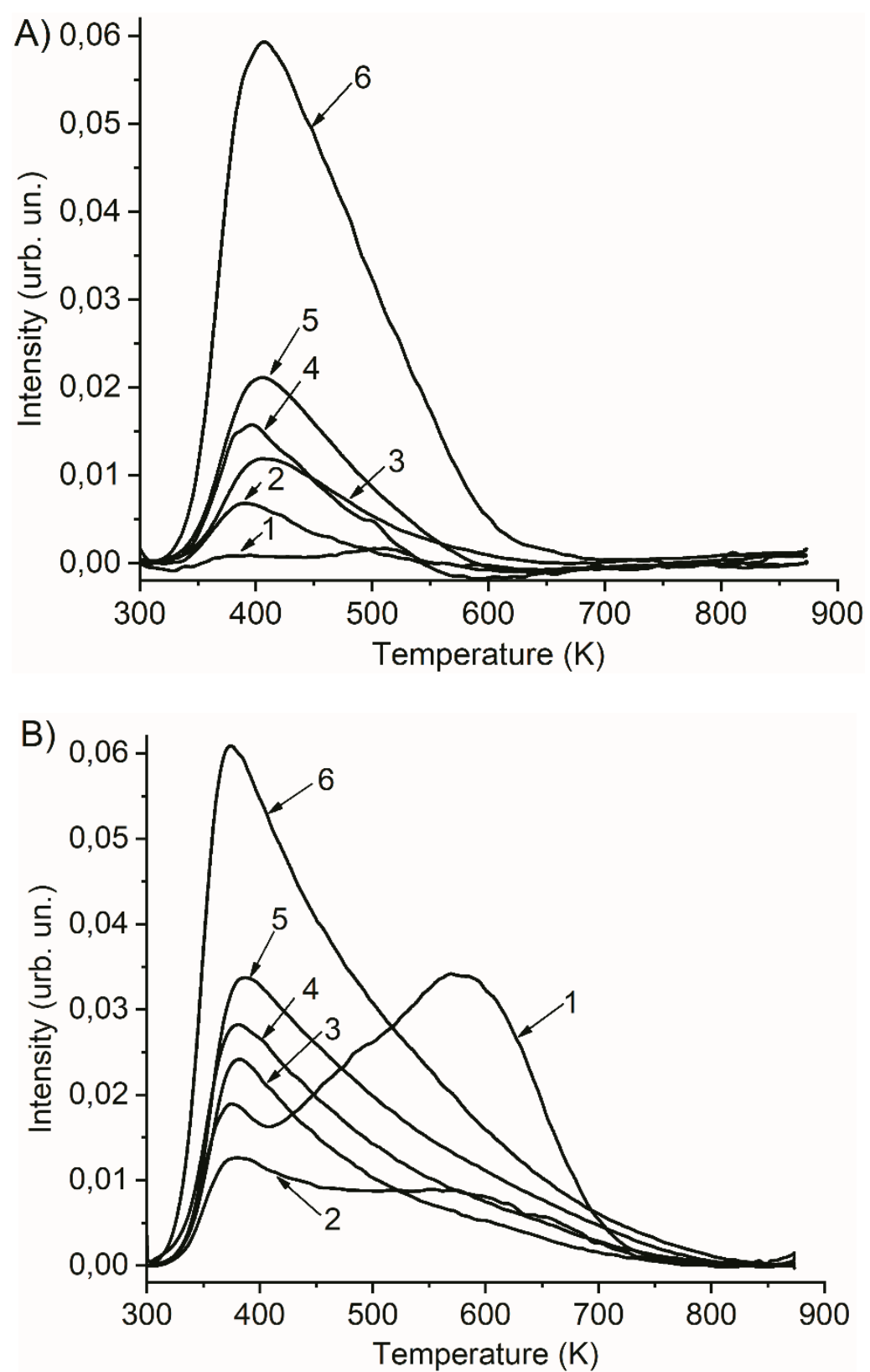

Figure S9. $\mathrm{NH}_{3}$-TPD-MS (A) and $\mathrm{CO}_{2}$-TPD-MS (B) profiles for the samples: $1-\mathrm{AC}, 2-20 \mathrm{Mg}-\mathrm{Al} / \mathrm{AC}, 3-30 \mathrm{Mg}-\mathrm{Al} / \mathrm{AC}, 4-$ 40Mg-Al/AC, 5 - 50Mg-Al/AC, 6 - Mg-Al. 

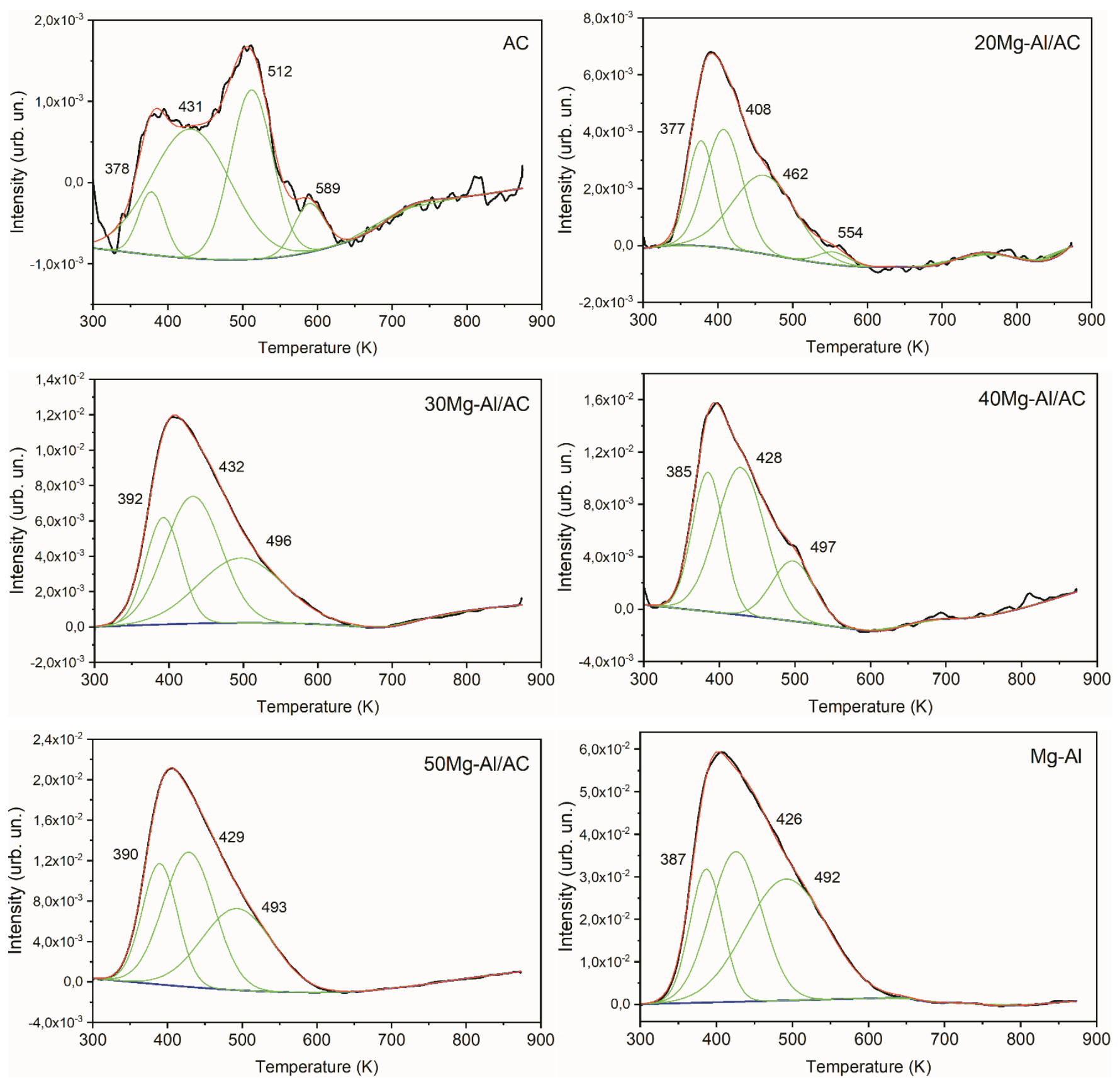

Figure S10. $\mathrm{NH}_{3}$-TPD-MS profiles for the samples and the corresponding fitting curves. 

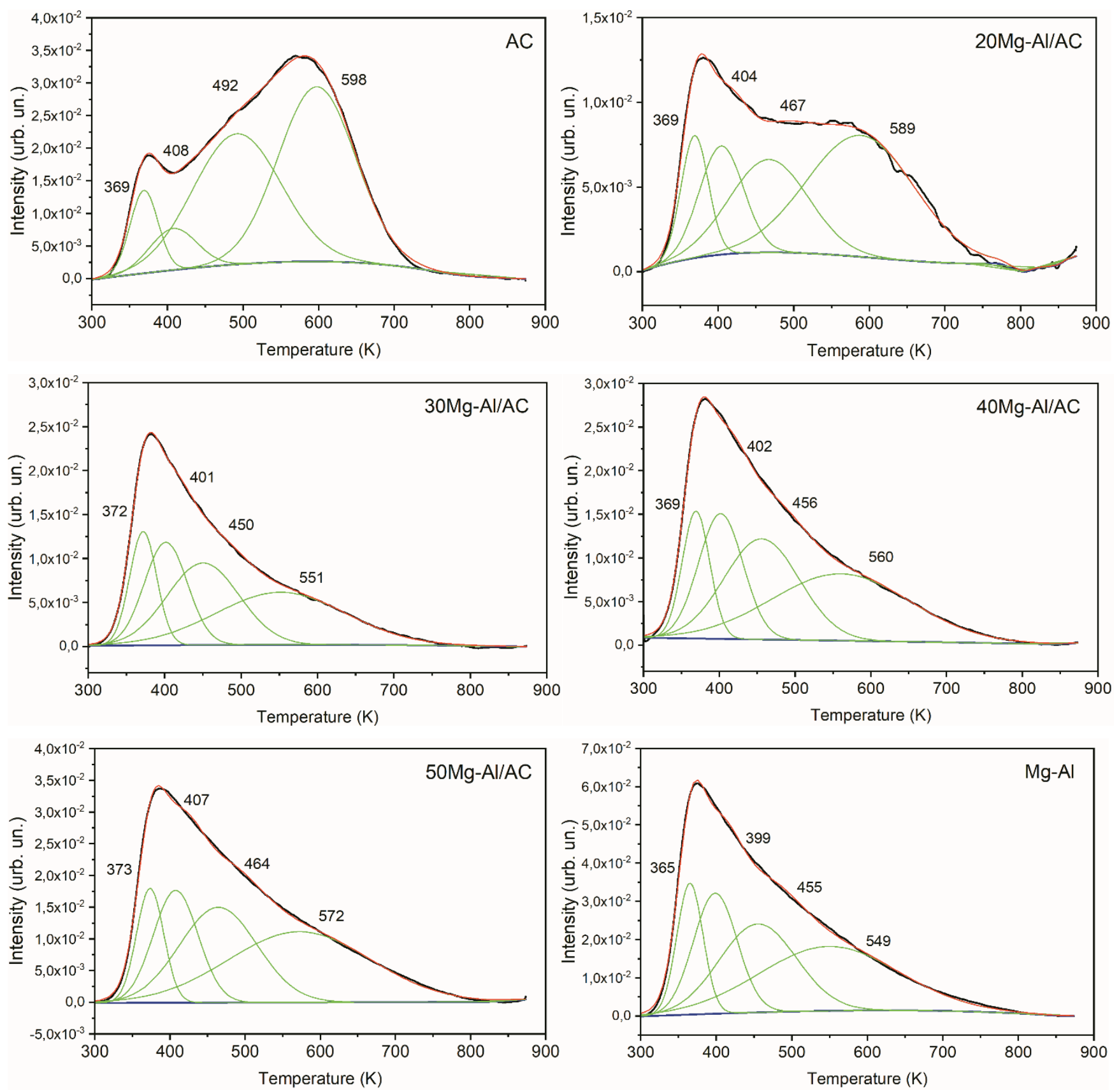

Figure S11. $\mathrm{CO}_{2}$-TPD-MS profiles for the samples and the corresponding fitting curves. 

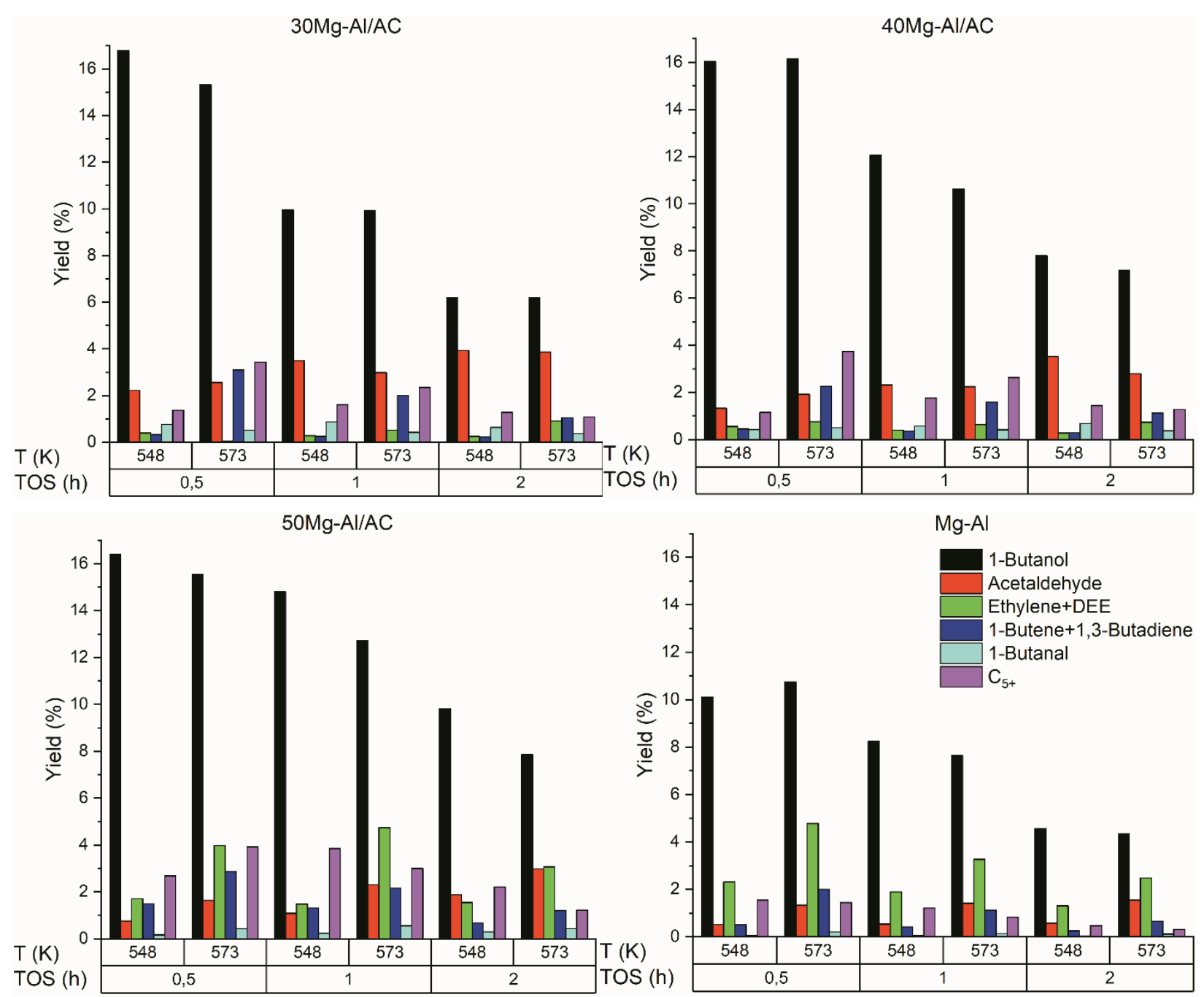

Figure S12. Temperature dependencies of the yield of the main products during the conversion of ethanol (95.6 vol\%) over Mg$\mathrm{Al}$ oxide and $\mathrm{Mg}-\mathrm{Al} / \mathrm{AC}$ hybrid catalysts. Reaction conditions: $\mathrm{LHSV}=0.14 \mathrm{~L} \cdot \mathrm{L}_{\mathrm{cat}}{ }^{-1} \cdot \mathrm{h}^{-1}$.

An increase in the process temperature causes some increase in the yield of the target product (1-butanol) in the presence of $40 \mathrm{Mg}-\mathrm{Al} / \mathrm{AC}$ and $\mathrm{Mg}-\mathrm{Al}$ catalysts at TOS $=0.5 \mathrm{~h}$ (Figure S10), however, the yield of 1-butanol decreases at TOS $>1 \mathrm{~h} . \mathrm{In}$ the presence of $30 \mathrm{Mg}-\mathrm{Al} / \mathrm{AC}$ and $50 \mathrm{Mg}-\mathrm{Al} / \mathrm{AC}, 1$-butanol yield decreases with an increase in temperature at various TOS. The tendency to change the yield of ethanol dehydrogenation product (acetaldehyde) with increasing process temperature by $25 \mathrm{~K}$ is slightly different: at TOS $=0.5 \mathrm{~h}$, the yield of acetaldehyde increases, and at TOS $>1 \mathrm{~h}$, decreases. The number of the byproducts of ethanol conversion increases too, namely ethylene, DEE, 1-butene, 1,3-butadiene and $\mathrm{C}_{5+}$-products. The absolute change in the yield of 1-butanal does not exceed $0.5 \%$ over all studied catalysts. 
$\mathrm{Mg}-\mathrm{Al}$
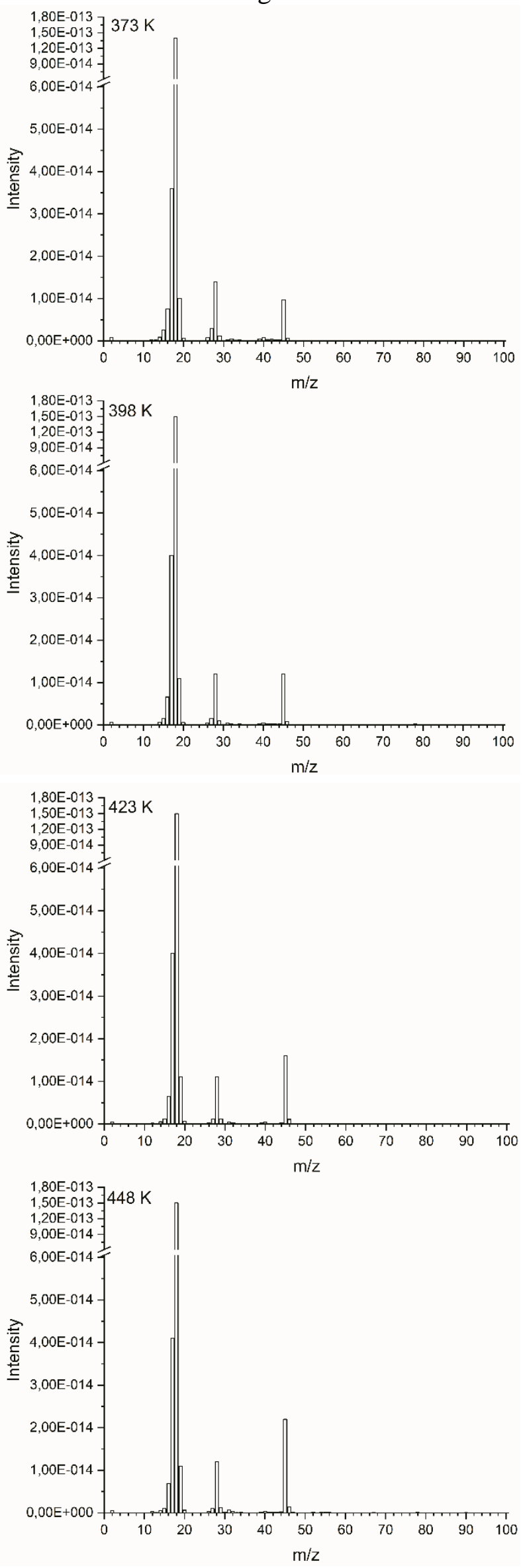

Mg-Al/AC
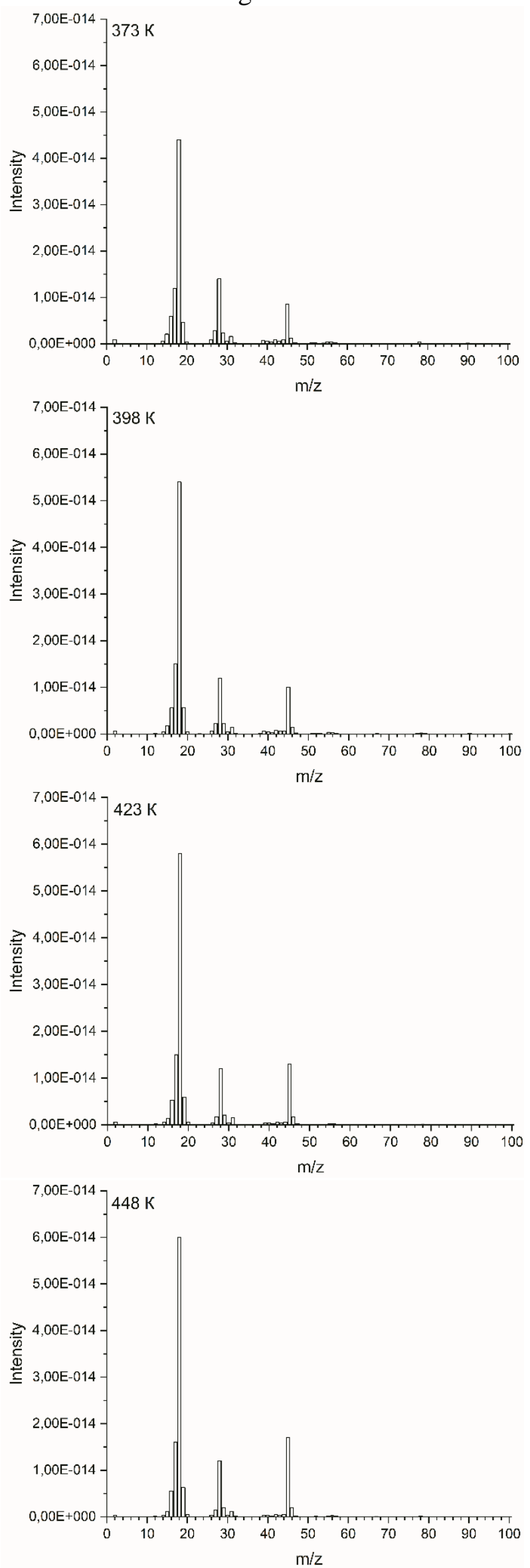

Figure S13. TPD-MS profiles of the $\mathrm{Mg}-\mathrm{Al}$ and $40 \mathrm{Mg}-\mathrm{Al} / \mathrm{AC}$ samples after catalysis. Reaction conditions: $\mathrm{TOS}=4 \mathrm{~h}, \mathrm{~T}=$ $548 \mathrm{~K}$. 
$\mathrm{Mg}-\mathrm{Al}$
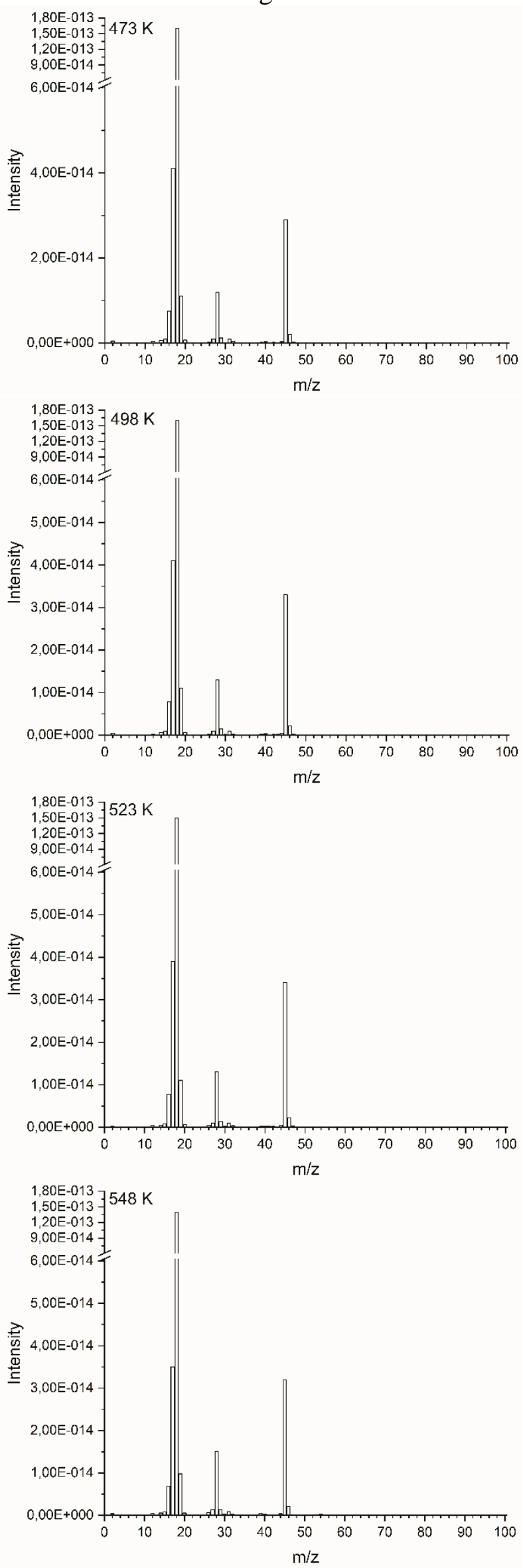

Mg-Al/AC
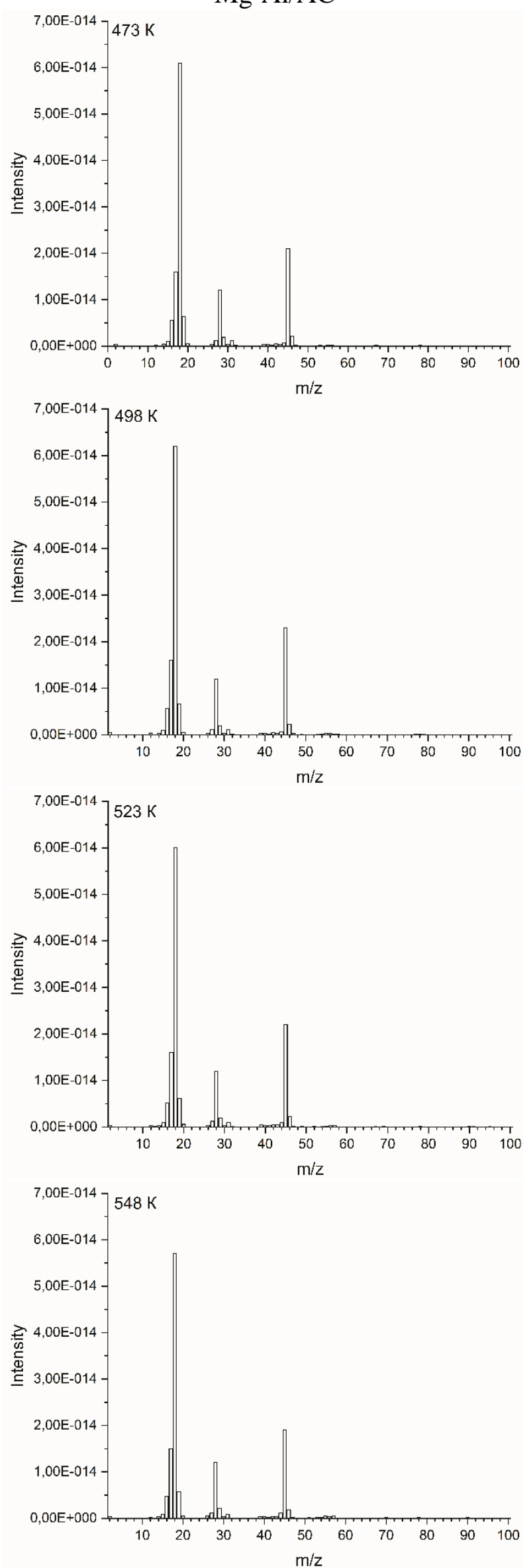

Figure S13 (continuation). TPD-MS profiles of the $\mathrm{Mg}-\mathrm{Al}$ and $40 \mathrm{Mg}-\mathrm{Al} / \mathrm{AC}$ samples after catalysis. Reaction conditions: $\mathrm{TOS}=4 \mathrm{~h}, \mathrm{~T}=548 \mathrm{~K}$. 


\section{$\mathrm{Mg}-\mathrm{Al}$}
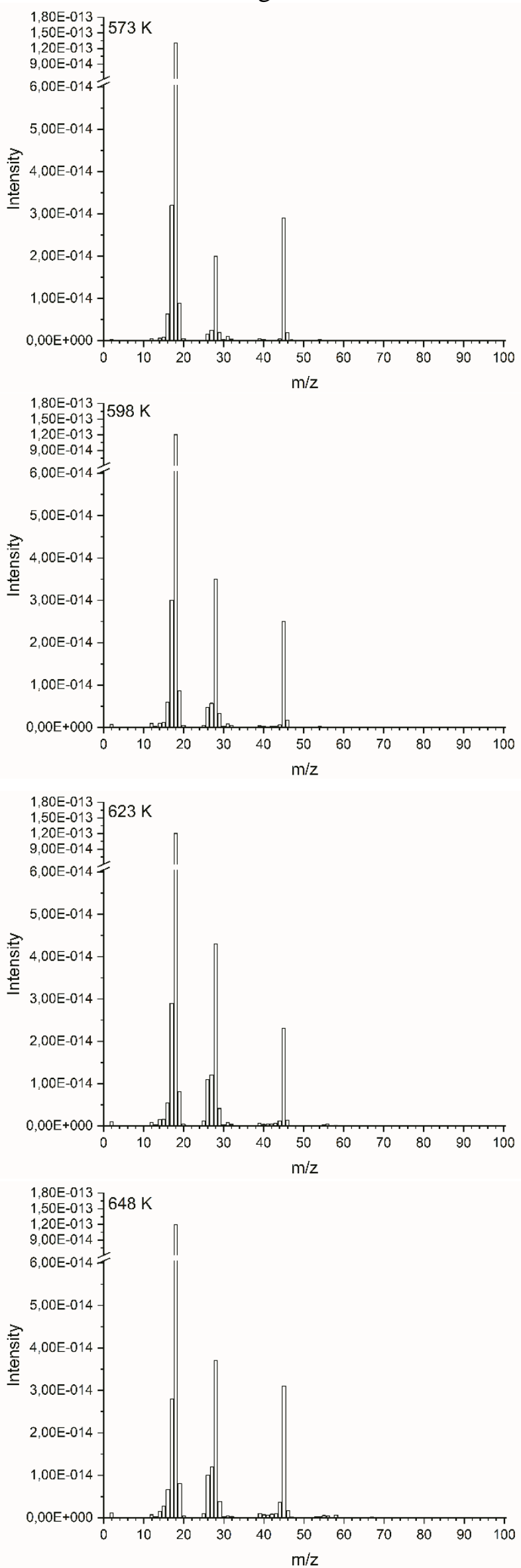

Mg-Al/AC
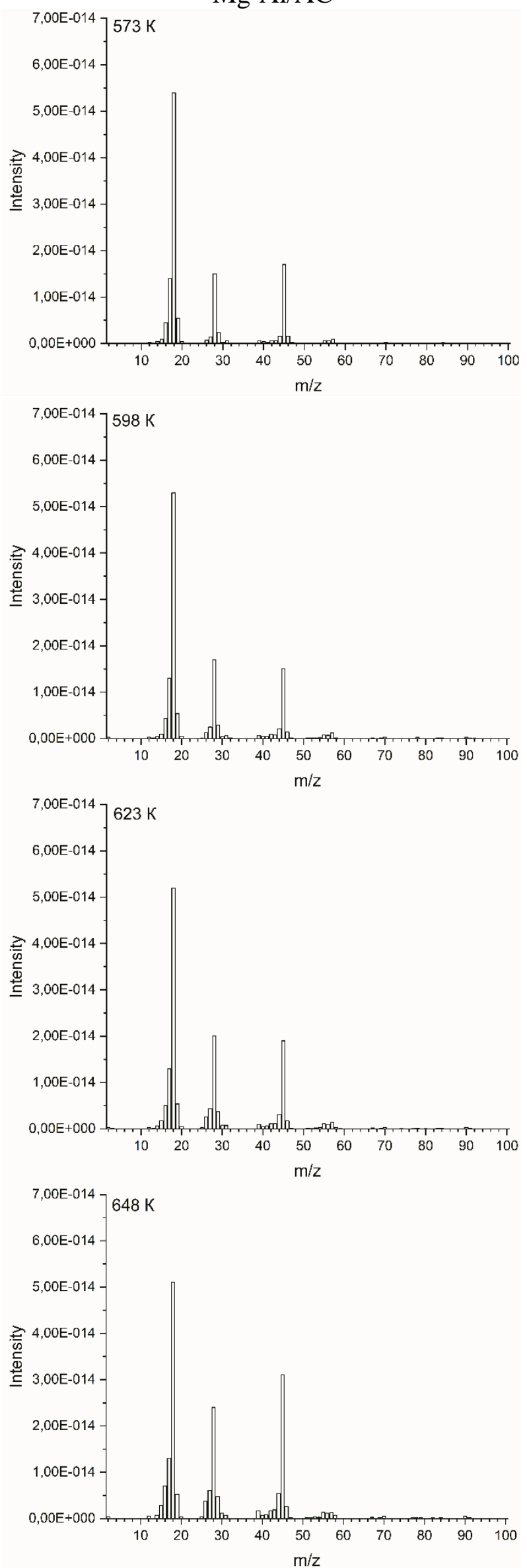

Figure S13 (continuation). TPD-MS profiles of the $\mathrm{Mg}-\mathrm{Al}$ and 40Mg-Al/AC samples after catalysis. Reaction conditions: $\mathrm{TOS}=4 \mathrm{~h}, \mathrm{~T}=548 \mathrm{~K}$. 


\section{$\mathrm{Mg}-\mathrm{Al}$}
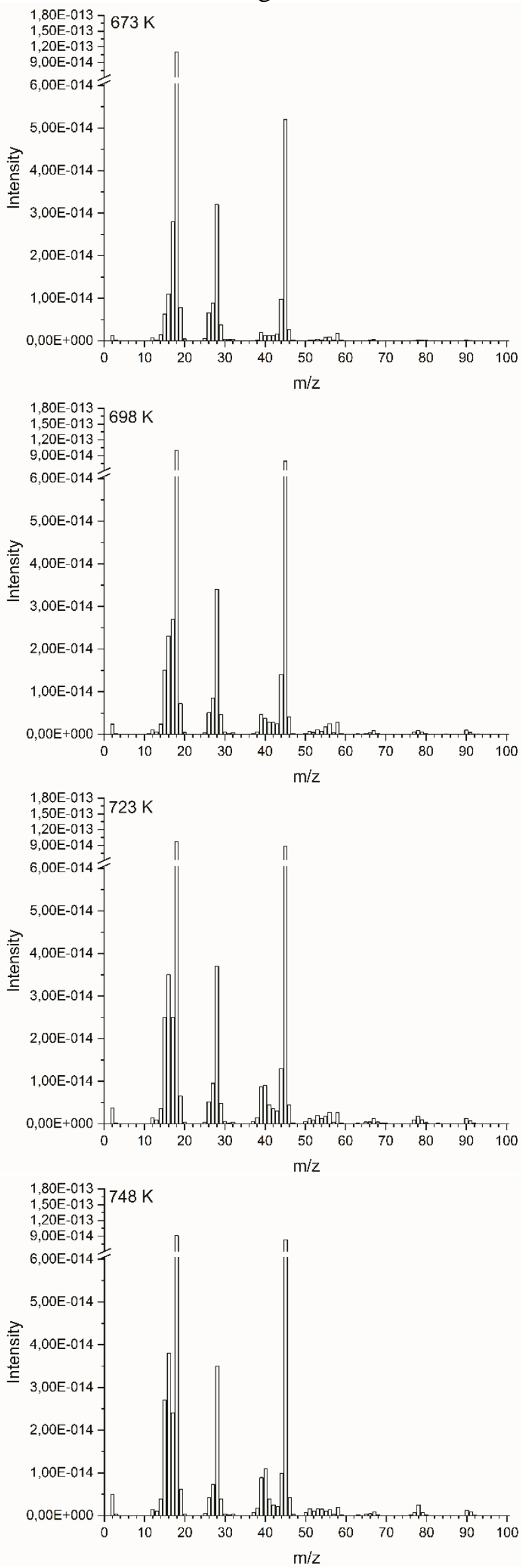

Mg-Al/AC
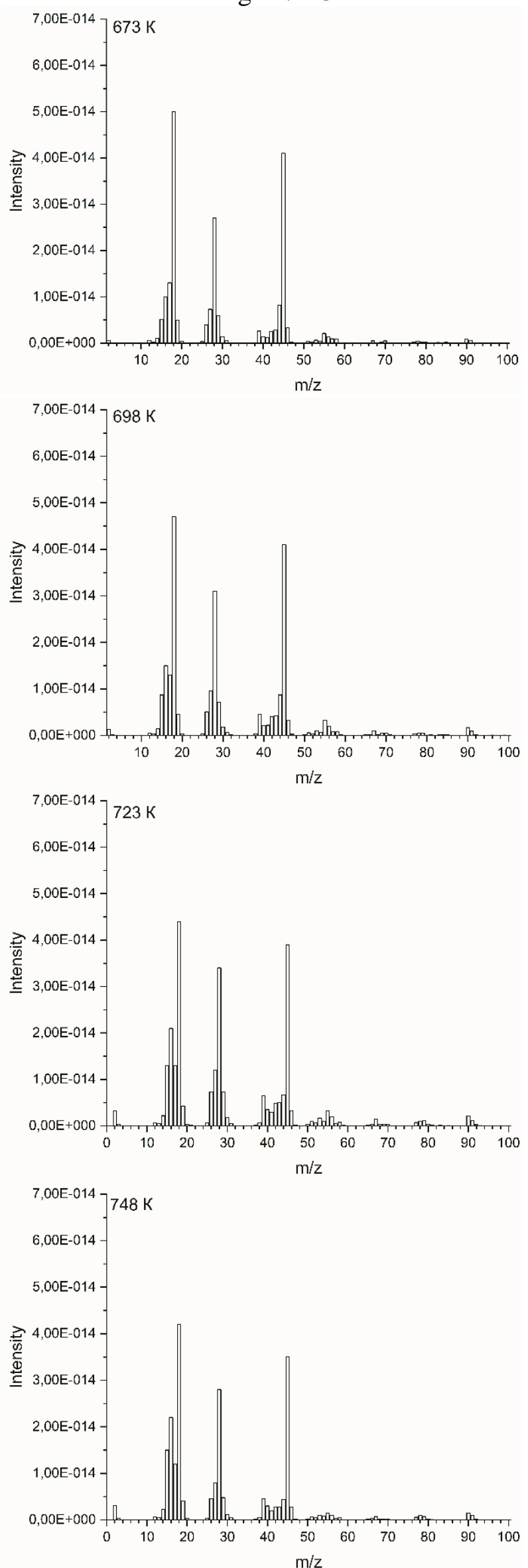

Figure S13 (continuation). TPD-MS profiles of the $\mathrm{Mg}-\mathrm{Al}$ and 40Mg-Al/AC samples after catalysis. Reaction conditions: $\mathrm{TOS}=4 \mathrm{~h}, \mathrm{~T}=548 \mathrm{~K}$. 

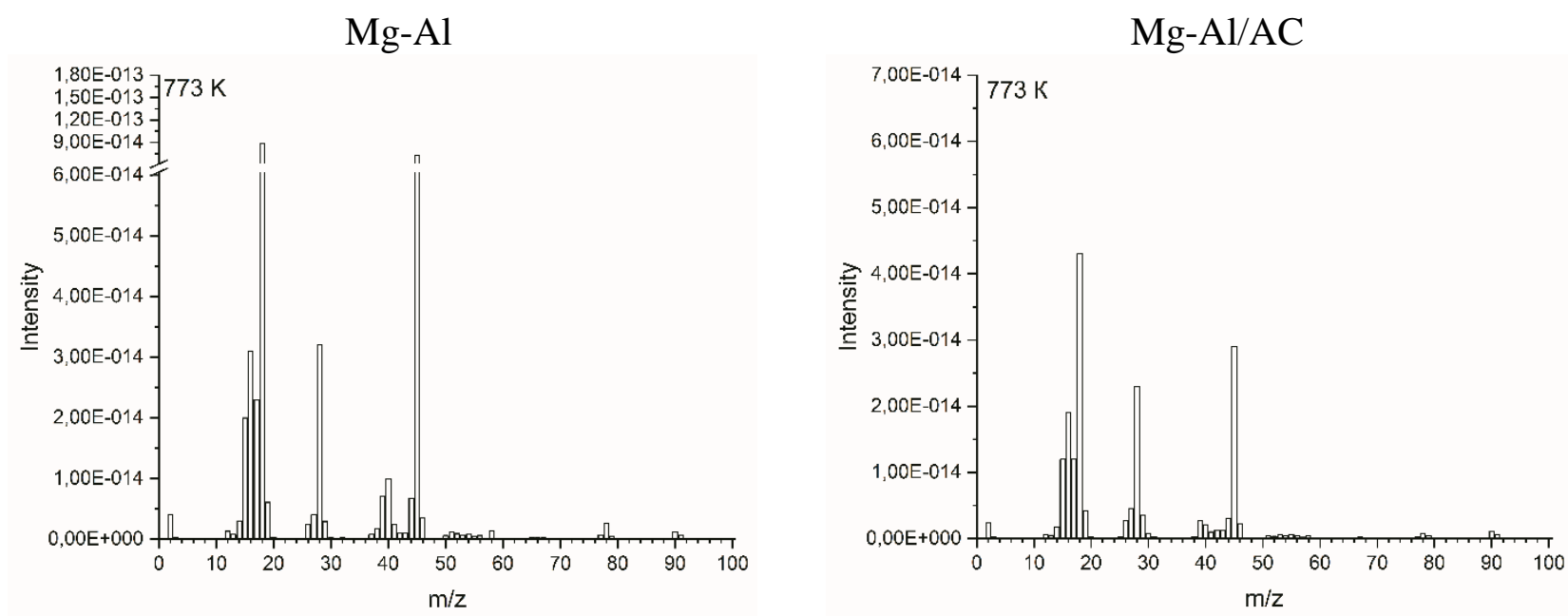

Figure S13 (continuation). TPD-MS profiles of the $\mathrm{Mg}-\mathrm{Al}$ and $40 \mathrm{Mg}-\mathrm{Al} / \mathrm{AC}$ samples after catalysis. Reaction conditions: $\mathrm{TOS}=4 \mathrm{~h}, \mathrm{~T}=548 \mathrm{~K}$.

Figure S13 shows TPD-MS profiles of the Mg-Al and Mg-Al/AC samples after catalysis at $548 \mathrm{~K}$. Time-on-stream (TOS) of $4 \mathrm{~h}$ was chosen, because the values of ethanol conversion and the yield of 1-butanol are reduced during the initial reaction hours. Ethanol $(\mathrm{m} / \mathrm{z}=45)$, ethylene as a product of the temperature programmed surface reaction of ethanol dehydration $(\mathrm{m} / \mathrm{z}=28)$, and $\mathrm{H}_{2} \mathrm{O}(\mathrm{m} / \mathrm{z}=18)$ are the main desorption products from the surface of both samples. The intensity of $\mathrm{H}_{2} \mathrm{O}$ signal is much higher than others indicating the presence of preferably $\mathrm{H}_{2} \mathrm{O}$ adsorbed on the catalyst surface. Meanwhile, throughout the desorption temperature range (373-773 K) the intensity of $\mathrm{H}_{2} \mathrm{O}$ signal for $\mathrm{Mg}-\mathrm{Al}$ sample is higher than for $\mathrm{Mg}-\mathrm{Al} / \mathrm{AC}$, which is consistent with the $\mathrm{H}_{2} \mathrm{O}-\mathrm{TPD}-\mathrm{MS}$ results (Figure 5). The intensities of ethanol and ethylene signals are comparable for both catalysts, which may indicate the availability of the same number of ethanol adsorption sites on the catalyst surface after partial deactivation for $4 \mathrm{~h}$. At temperatures above $673 \mathrm{~K}$ there are the signals in the ranges $\mathrm{m} / \mathrm{z}=39-46 \mathrm{and} \mathrm{m} / \mathrm{z}=$ more than 50 . These signals can be attributed to the products of deep condensation of ethanol. 2-Ethyl-1-hexanal is identified with m/z values: 27, 29, 41, 43, and 57. Hexanal is identified with $\mathrm{m} / \mathrm{z}$ values: 27, 29, 41, 43, 44, 56, and 57. 2,4-Dimethyl-benzaldehyde is identified with $\mathrm{m} / \mathrm{z}$ values: $39,50-53,77-79$, and 91 . The latter was also identified in the organic compounds adsorbed over Zn-Y/Beta catalyst surface after the ethanol-to-butadiene conversion. ${ }^{6}$ It should be mentioned that the intensity of $\mathrm{H}_{2} \mathrm{O}$ signal is much higher than that of organic products for both studied catalysts. Therefore, $\mathrm{H}_{2} \mathrm{O}$ adsorption over acid and basic sites of the catalyst surface is suggested to be the main reason of the catalyst deactivation in the Guerbet condensation of ethanol during the initial reaction hours. 

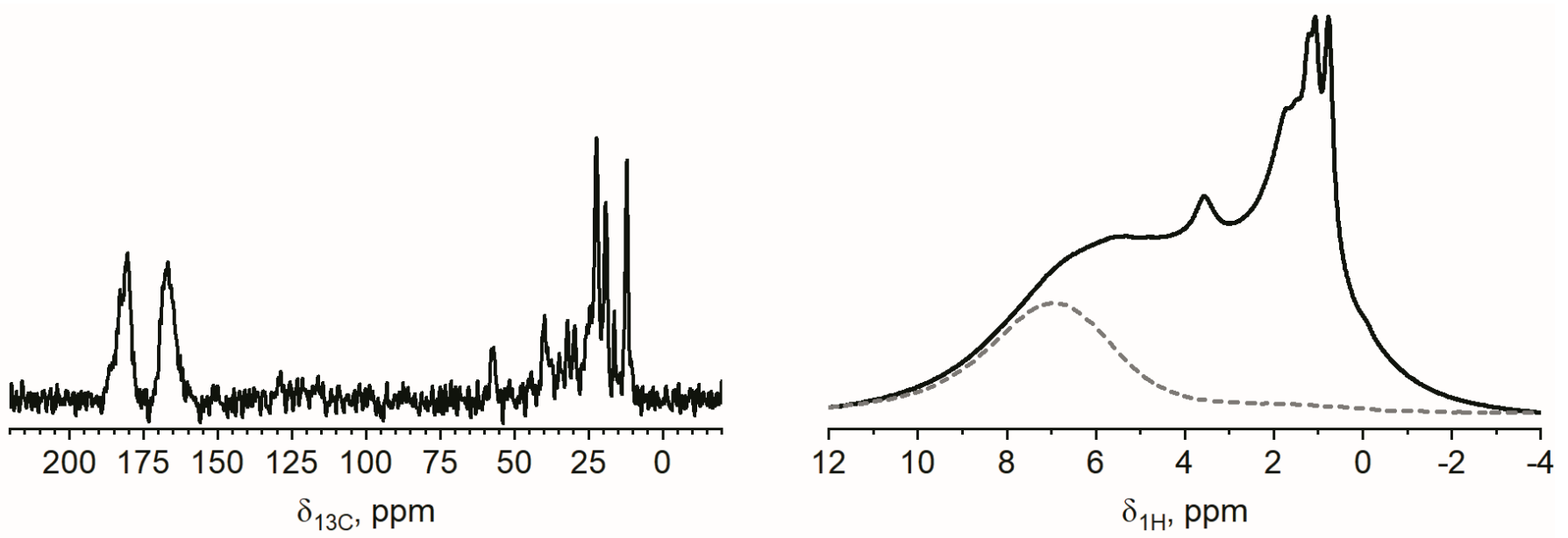

Figure S14. ${ }^{1} \mathrm{H}^{-13} \mathrm{C}$ CP/MAS and ${ }^{1} \mathrm{H}$ MAS NMR spectra of the Mg-Al sample after catalysis. Reaction conditions: $\mathrm{TOS}=8 \mathrm{~h}$, $\mathrm{T}=573 \mathrm{~K}$. The background (grey short dash line) is presented for reference.

To investigate organic deposits on spent $\mathrm{Mg}-\mathrm{Al}$ sample and to evaluate mechanistic aspects of catalyst deactivation, ${ }^{1} \mathrm{H}-{ }^{13} \mathrm{C}$ CP/MAS and ${ }^{1} \mathrm{H}$ MAS NMR measurements are performed after ethanol-to-1-butanol conversion at $573 \mathrm{~K}$ for TOS of $8 \mathrm{~h}$ (Figure S14). Since a contribution of ${ }^{1} \mathrm{H}$ NMR signals attributed to surface hydroxyls of the sample is small, strong ${ }^{1} \mathrm{H}$ NMR signals in the range from 4 to $0 \mathrm{ppm}$ result from adsorbed conversion products and reagents. There are ${ }^{13} \mathrm{C}$ NMR signals at $10-25 \mathrm{ppm}$ and 25-50 ppm due to primary carbon atoms in $\mathrm{CH}_{3}-\mathrm{R}$ and $\mathrm{R}-\mathrm{CH}_{2}-\mathrm{R}$ compounds. ${ }^{13} \mathrm{C}$ NMR signals at $55-60 \mathrm{ppm}$ can reflect the presence of carbon atoms in $-\mathrm{CH}_{2}-\mathrm{O}-$ and $\mathrm{CH}_{3}-\mathrm{O}-$ functional groups and/or tertiary carbon atoms like $\mathrm{CH}(-\mathrm{R}) 3 .{ }^{13} \mathrm{C}$ NMR signals at 155-175 ppm and 175-190 ppm are likely to result from carbon atom resonances of ester and acid compounds. Adsorbed ethanol $\left(\delta^{13} \mathrm{C}=57\right.$ and $16 \mathrm{ppm}, \delta^{1} \mathrm{H}=3.6$ and $\left.1.1 \mathrm{ppm}\right)$, acetic acid $\left(\delta^{13} \mathrm{C}=\sim 182\right.$ and $\left.22 \mathrm{ppm}, \delta^{1} \mathrm{H}=\sim 1.8 \mathrm{ppm}\right)$ and acetate compounds $\left(\delta^{13} \mathrm{C}=\sim 167 \mathrm{ppm}\right)^{7,8}$ are suggested to be on the surface of $\mathrm{Mg}$-Al sample. After ethylene adsorption straightchain $\left(\delta^{13} \mathrm{C}=12,25,30-33 \mathrm{ppm}\right)$ and branched $\left(\delta^{13} \mathrm{C}=40 \mathrm{ppm}\right)$ paraffinic oligomers are formed. Therefore, the products of deep condensation of ethanol/acetaldehyde are deposited on the catalyst surface. 
Table S1. Acid-base characteristics obtained from the deconvolution of $\mathrm{NH}_{3}-\mathrm{TPD}-\mathrm{MS}$ and $\mathrm{CO}_{2}-\mathrm{TPD}-\mathrm{MS}$ spectra of the samples.

\begin{tabular}{|c|c|c|c|c|c|c|c|}
\hline \multirow[t]{2}{*}{ Characteristics } & \multirow{2}{*}{$\begin{array}{l}\text { Temperature of } \mathrm{NH}_{3} \text { and } \mathrm{CO}_{2} \\
\text { desorption peak maxima, } \mathrm{K}\end{array}$} & \multicolumn{6}{|c|}{ Samples } \\
\hline & & $\mathrm{AC}$ & $\begin{array}{l}20 \mathrm{Mg}- \\
\mathrm{Al} / \mathrm{AC}\end{array}$ & $\begin{array}{l}30 \mathrm{Mg}- \\
\mathrm{Al} / \mathrm{AC}\end{array}$ & $\begin{array}{l}40 \mathrm{Mg}- \\
\mathrm{Al} / \mathrm{AC}\end{array}$ & $\begin{array}{l}50 \mathrm{Mg}- \\
\mathrm{Al} / \mathrm{AC}\end{array}$ & $\mathrm{Mg}-\mathrm{Al}$ \\
\hline \multirow{5}{*}{$\begin{array}{l}\text { Acidity, } \\
\mu \mathrm{mol} / \mathrm{g}\end{array}$} & $377-392$ & 0.6 & 3.1 & 6.7 & 10.2 & 13.0 & 31.5 \\
\hline & $408-432$ & 3.9 & 4.8 & 12.6 & 16.9 & 21.1 & 55.4 \\
\hline & $462-512$ & 2.8 & 5.4 & 9.6 & 5.9 & 17.8 & 70.7 \\
\hline & 554-589 & 0.6 & 0.4 & - & - & - & - \\
\hline & Total & 7.8 & 13.7 & 28.9 & 33.0 & 51.9 & 157.6 \\
\hline \multirow{5}{*}{$\begin{array}{l}\text { Basicity, } \\
\mu \mathrm{mol} / \mathrm{g}\end{array}$} & $365-373$ & 9.6 & 5.4 & 9.3 & 10.7 & 13.3 & 24.2 \\
\hline & 399-408 & 8.1 & 7.6 & 13.3 & 17.2 & 21.5 & 37.1 \\
\hline & $450-492$ & 47.4 & 11.6 & 17.9 & 23.3 & 31.6 & 48.0 \\
\hline & 549-598 & 55.8 & 20.7 & 20.5 & 28.5 & 42.8 & 62.6 \\
\hline & Total & 120.9 & 45.2 & 61.0 & 79.7 & 109.2 & 172.0 \\
\hline \multirow{5}{*}{$\begin{array}{l}\text { Specific acidity, } \\
\mathrm{nmol} / \mathrm{m}^{2}\end{array}$} & $377-392$ & 0.5 & 3.8 & 9.3 & 15.4 & 23.4 & 190.8 \\
\hline & $408-432$ & 3.4 & 5.8 & 17.5 & 25.5 & 38.0 & 335.6 \\
\hline & $462-512$ & 2.4 & 6.5 & 13.4 & 9.0 & 32.0 & 428.8 \\
\hline & 554-589 & 0.5 & 0.4 & - & - & - & - \\
\hline & Total & 6.8 & 16.5 & 40.1 & 49.9 & 93.4 & 955.2 \\
\hline \multirow{5}{*}{$\begin{array}{l}\text { Specific basicity, } \\
\mathrm{nmol} / \mathrm{m}^{2}\end{array}$} & $365-373$ & 8.4 & 6.5 & 12.9 & 16.3 & 24.0 & 146.9 \\
\hline & $399-408$ & 7.1 & 9.2 & 18.5 & 26.1 & 38.7 & 224.9 \\
\hline & $450-492$ & 41.4 & 13.9 & 24.9 & 35.3 & 56.9 & 290.9 \\
\hline & 549-598 & 48.7 & 24.9 & 28.5 & 43.1 & 77.1 & 379.7 \\
\hline & Total & 105.6 & 54.5 & 84.8 & $\begin{array}{l}120.8 \\
\end{array}$ & 196.7 & 1042.4 \\
\hline \multicolumn{2}{|c|}{ Acid-base capacity ratio } & 0.06 & 0.27 & 0.42 & 0.36 & 0.42 & 0.81 \\
\hline
\end{tabular}




\section{References}

(1) Rodrigues, E.; Pereira, P.; Martins, T.; Vargas, F.; Scheller, T.; Correa, J.; Del Nero, J.; Moreira, S. G. C.; ErtelIngrisch, W.; De Campos, C. P.; et al. Novel rare earth (Ce and La) hydrotalcite like material: Synthesis and characterization. Mater. Lett. 2012, 78, 195-198.

(2) Mališová, M.; Horňáček, M.; Mikulec, J.; Hudec, P.; Jorík, V. FTIR study of hydrotalcite. Acta Chim. Slovaca 2018, $11(2), 147-156$.

(3) Velázquez-Herrera, F. D.; Fetter, G. Hydrotalcites with heterogeneous anion distributions: a first approach to producing new materials to be used as vehicles for the successive delivery of compounds. Clay Miner. 2020, 55, 3139.

(4) Kuśtrowski, P.; Sułkowska, D.; Chmielarz, L.; Rafalska-Łasocha, A.; Dudek, B.; Dziembaj, R. Influence of thermal treatment conditions on the activity of hydrotalcite-derived $\mathrm{Mg}$ - $\mathrm{Al}$ oxides in the aldol condensation of acetone. Microporous Mesoporous Mater. 2005, 78 (1), 11-22.

(5) Wiyantoko, B.; Kurniawati, P.; Purbaningtias, T. E.; Fatimah, I. Synthesis and Characterization of Hydrotalcite at Different Mg/Al Molar Ratios. Procedia Chem. 2015, 17, 21-26.

(6) Yan, T.; Yang, L.; Dai, W.; Wang, C.; Wu, G.; Guan, N.; Hunger, M.; Li, L. On the deactivation mechanism of zeolite catalyst in ethanol to butadiene conversion. J. Catal. 2018, 367, 7-15.

(7) Liang, S. H. C.; Gay, I. D. A 13C solid-state NMR study of the chemisorption and decomposition of ethanol on MgO. J. Catal. 1986, 101 (2), 293-300.

(8) Pretsch, E.; Bühlmann, P.; Affolter, C. Structure Determination of Organic Compounds: tables of spectral data; Springer: Berlin ; Heidelberg ; New York ; Barcelona ; Hong Kong ; London ; Milan ; Paris ; Singapore ; Tokyo, 2000. 